\title{
TREATMENT OF PATIENTS WITH HYPERBARIC OXYGEN IN THE DEPARTMENT OF HYPERBARIC MEDICINE IN MBAL VARNA VMA
}

\author{
Yaneva M. ${ }^{1}$, D. Stavrev ${ }^{2}$, Hr. Bozov ${ }^{3}$ \\ ${ }^{1}$ Department of Hyperbaric medicine, VMA MBAL; ${ }^{2}$ Department of Anatomy, Histology and \\ Embriology, ${ }^{3}$ Department of General and Operative Surgery, Anesthesiology and Intensive Care, \\ Medical University "Prof. Paraskev Stoyanov" - Varna
}

Reviewed by: assoc. prof. V. Platikanov

\section{SUMMARY}

\begin{abstract}
Slowly but surely, hyperbaric oxygenation is established as a method of treatment for many diseases. Aim of our work is to present the experience of the Department of hyperbaric medicine at VMA MBAL Varna in the treatment of patients with Hyperbaric Oxygen. The study covers the period 1992-2011. A multiplace hyperbaric chamber at a pressure of 2 to 2.8 ATA $100 \%$ oxygen is used.It is analyzed distribution of patients passed through the department by years and nosological units. It is concluded that it has gained solid experience, which is a good basis for further development and expansion of indications for hyperbaric oxygenation.
\end{abstract}

Key words: hyperbaric oxigenation, hyperbaric chamber

\section{INTRODUCTION}

Slowly but surely, hyperbaric medicine is becoming an established treatment modality for a variety of medical disorders although used relatively recently, the fifties of the $20^{\text {th }}$ century and primarily in the developed maritime countries. Globally, there is still no uniform indications for use. In the U.S., HBO therapy is used in 12 groups of diseases, this standard was prepared by the Association of hyperbaric and undersea medicine for the U.S. (UHMS). European medical society in the last 15 years actively engaged in identifying the site of hyperbaric medicine in clinical practice, led to a European code of quality practice in hyperbaric oxygenation /May 2004/.

\section{PURPOSE}

Our goal was to present our experience with $\mathrm{HBO}$ in various diseases.

\section{MATERIALS AND METHODS}

The study covers the period from 1992 to 2011 . Methods applied in the study: analysis of literary sources, documen-

Address for correspondence:

M. Yaneva, Dept. of Hyperbaric medicine, VMA MBAL

3 Hristo Smirnenski Str., Bulgaria, Varna 9000

e-mail: yanevahbo@abv.bg tary method, a comparative analysis. The data were processed by statistical and graphical analysis.

\section{RESULTS AND DISCUSSION}

For a period of 20 years in the Department of Hyperbaric Medicine at VMB 3926 patients have undergone. The trend of number of patients treated with hyperbaric therapy method is generally increasing for the period. There is some decrease in the number of patients for the years 1999 to 2003 and from 2004 to the present moment the number of patients grows. We can make a comment why we believe. The largest share for patients with otorhinolaryngological diseases 1515 or $38.6 \%$. They are more than one third of a course of hyperbaric oxygenation. The next in number are those with 734 or surgical diseases $18.7 \%$. These two categories of patients are more than half using $\mathrm{HBO}$.

Some specific pathologies are subject to treatment only in hyperbaric chamber and this makes them of special interest. Second time to turn our attention to them is that they always present state of urgency. In this group belong patients with divers diseases and poisoning with carbon monoxide. The number of cases is respectively 151 or 3.8\% for diving illnesses and 402 or $10.2 \%$ for poisoning.

The largest number of cases to treat divers there in 1996. The number of cases of this type was significantly greater in the first half of the period. From 2002 until the number of diving diseases is definitely decreased. Only once /2007/. It exceeds 10. In the recent years there has been increased awareness of diving risks and how to avoid them. On the 
Table 1

\begin{tabular}{|c|c|c|c|c|c|c|c|c|c|c|c|c|c|c|c|c|c|c|c|c|c|}
\hline $\begin{array}{c}\text { years/ } \\
\text { noso- } \\
\text { logical } \\
\text { units }\end{array}$ & $\tilde{\sigma}$ & ڤ̆ & 亏ั & ڤั & Бे & $\hat{\sigma}$ & $\stackrel{\infty}{\sigma}$ & Бे & ఫ్సి & ธ్ & ฮิ่ & હิે & હે & 气્సે & ఫ్సે & ક્సે & ڤ్ ેి & ڤ్సે & ิㅗำ & $\overline{\bar{ก}}$ & 音 \\
\hline $\begin{array}{l}\text { surge- } \\
\text { ry }\end{array}$ & 6 & 33 & 58 & 43 & 43 & 40 & 46 & 37 & 25 & 15 & 21 & 20 & 43 & 37 & 50 & 28 & 51 & 48 & 48 & 42 & 734 \\
\hline $\begin{array}{l}\text { inter- } \\
\text { nal } \\
\text { disea- } \\
\text { ses }\end{array}$ & 1 & 21 & 23 & 21 & 30 & 17 & 53 & 52 & 34 & 17 & 15 & 5 & 14 & 15 & 19 & 9 & 18 & 15 & 3 & 8 & 390 \\
\hline $\begin{array}{l}\text { traum } \\
\text { atology }\end{array}$ & 1 & 10 & 13 & 11 & 7 & 9 & 21 & 31 & 27 & 15 & 17 & 5 & 7 & 13 & 23 & 19 & 18 & 24 & 12 & 37 & 320 \\
\hline $\begin{array}{l}\text { neuro- } \\
\text { rlogy }\end{array}$ & 1 & 20 & 19 & 47 & 56 & 27 & 30 & 29 & 14 & 6 & 8 & 11 & 10 & 17 & 15 & 7 & 13 & 28 & 30 & 26 & 414 \\
\hline $\begin{array}{l}\text { otorhi } \\
\text { nola- } \\
\text { ryngo- } \\
\text { logy }\end{array}$ & 2 & 5 & 10 & 15 & 42 & 37 & 54 & 40 & 43 & 15 & 12 & 9 & 40 & 85 & 135 & 209 & 132 & 166 & 219 & 245 & 1515 \\
\hline $\begin{array}{l}\text { diving } \\
\text { disea- } \\
\text { ses }\end{array}$ & 2 & 3 & 6 & 12 & 30 & 6 & 10 & 8 & 23 & 17 & 0 & 1 & 0 & 3 & 3 & 12 & 2 & 6 & 4 & 3 & 151 \\
\hline $\begin{array}{l}\text { toxico- } \\
\operatorname{logy}\end{array}$ & 4 & 30 & 20 & 30 & 38 & 43 & 46 & 15 & 14 & 12 & 1 & 0 & 6 & 9 & 25 & 31 & 26 & 24 & 13 & 15 & 402 \\
\hline total & 17 & 122 & 149 & 179 & 246 & 179 & 260 & 212 & 180 & 97 & 74 & 51 & 120 & 179 & 270 & 315 & 260 & 311 & 329 & 376 & 3926 \\
\hline
\end{tabular}

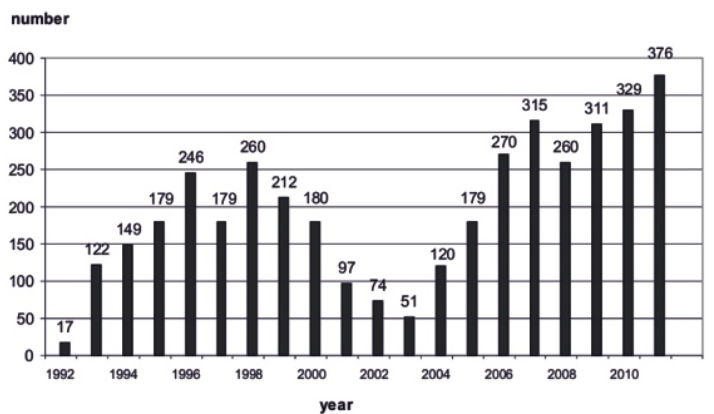

Fig. 1. Passed through the department of hyperbaric medicine patients

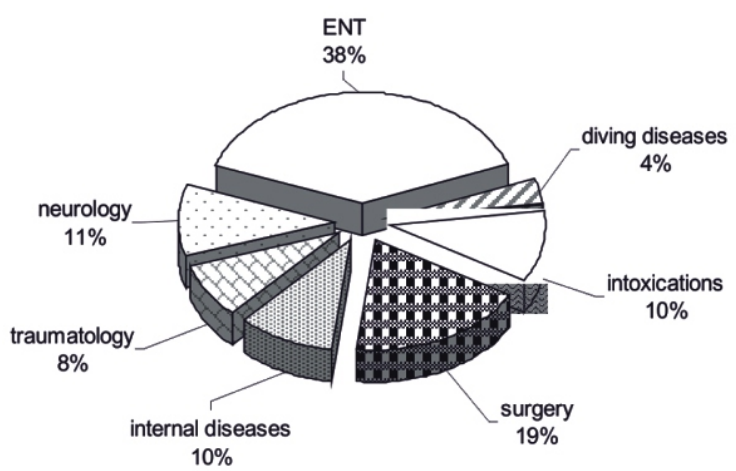

Fig. 2. Patients treated in the department of hyperbaric medicine for the period 1992-2011distribution by nosological units

other hand a growing number of physicians are interested and qualified in marine and diving medicine. It is not negli-

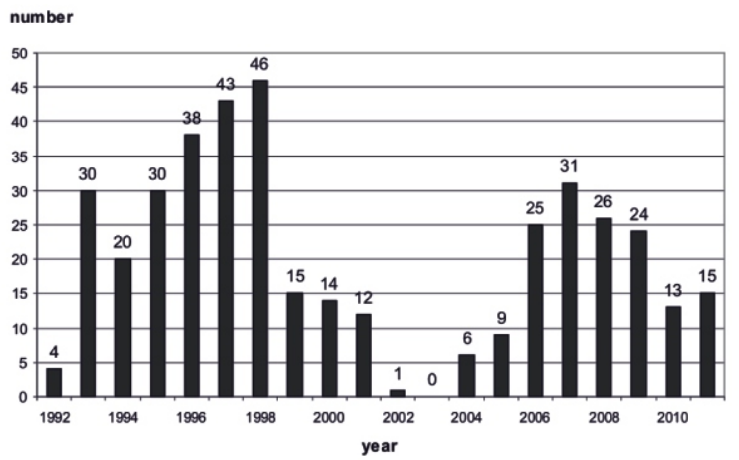

Fig. 3. Intoxications

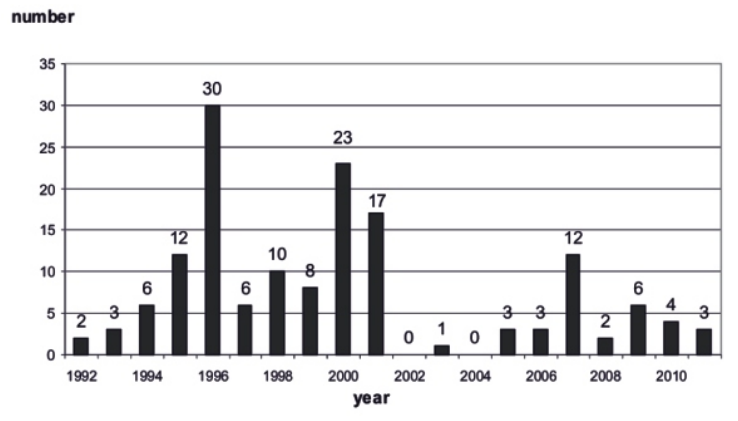

Fig. 4. Diving diseases

gible and that the decreased activity of gathering rapanas and related incidents.

The number of patients treated with intoxication is also a significant decrease for 2002-2004 year. Then the cases are 


\section{REFERENCES}

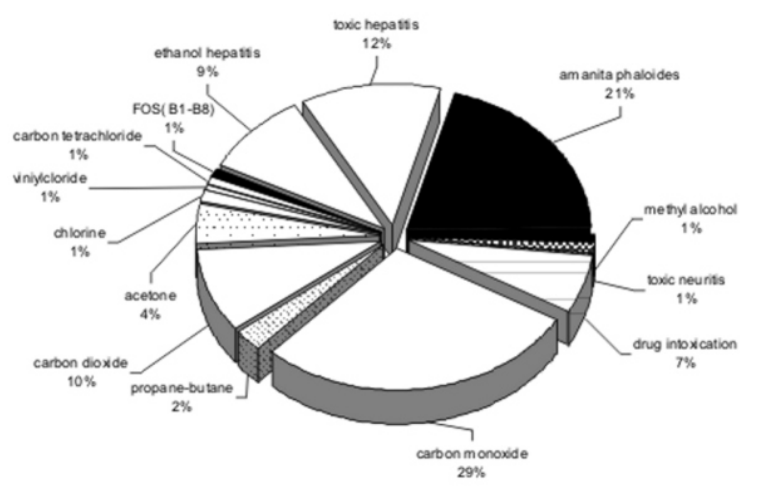

Fig. 5. Distribution of patients with intoxications by the type of toxic agent

increasing, but never reached the values of the first half of the period, but in recent years at levels $1 / 3$ of those years from 1996 to 1998.

Midst of intoxicating agents are: carbon monoxide, butane, carbon dioxide, acetone, chlorine, vinyl chloride, carbon tetrachloride, PHOS (BI-B8); ethyl alcohol, methyl alcohol, amanita faloides; drugs. The most significant proportion of them are carbon monoxide poisoning who are 99 or $28.7 \%$ of all intoxications. $\mathrm{CO}$ as a toxic agent is found both in industry and households. Source is the incomplete burning in combustion heaters, internal combustion engines, fires and other incidents.

\section{CONCLUSION}

During the twenty years period of its existence the Hyperbaric medicine department has gained a substantial experience with the HBO treatment of a lot of diseases. Our indications for $\mathrm{HBO}$ meet those of world leading authors in HBO. This experience is a solid base for further development and expanding indications of hyperbaric oxygenation.
1. Mathieu D, Niviere R, Lefebre-Lebleu N et al (1997) Anaerobic infections of soft tissues. Ann Chir 51: 272-287

2. Neubauer RA, Kagan RL, Gottlieb SF (1989) Use of hyperbaric oxygen for the treatment of aseptic bone necrosis: a case study. J Hyperbaric med 4: 69-76

3. Nilss on LP(1989) Effects of hyperbaric oxygen treatment on bone repair. Swedish Dental J 64(suppl);1-33

4. Nylander G, Lewis D, Nordstrom H, Larsson J (1985) Reduction of post-ischemic edema with hyperbaric oxygen. Plast Reconstr Surg 76: $596-603$

5. Nylander G, Nordstrom H, Franzen L et al (1988) Effects of hyperbaric oxygen ttreatment in post-ischemic muscle. Plast Reconstr Surg 79: 97-103.

6. Coulson DB, Ferguson AB, Diehl RC(1966) Effect of hyperbaric oxygen on healing femur of the rat. Surg forum 17:449.

7. Strauss MB (1987) Refractory osteomyelitis. $J$ Hyperbaric Med 2:147-159.

8. Strauss MB, Hart GB (1977) Clinical experience with $\mathrm{HBO}$ in fracture healing. Proceeding of the $7^{\text {th }}$ international congress of hyperbaric medicine. University of Aberdeen Press, Aberdeen, pp 329-332.

9. Dean BS, Verdile VP, Krenzelok EP. Coma reversal with cerebral dysfunction recovery afterrepetitive hyperbaric oxygen therapy for severe carbon monoxide poisoning.AmJEmergMed 1994 May;12 (3):389-90

10. Bozov H., M. Asparuchova. An application of HBO Benedetti S, Lamorgese A, Piersantelli M, Pagliarani S, Benvenuti F, Canestrari F. in CO intoxication. A social and economic cost. Balkan Military Medical Review. Volume 2, 1999, 139-141.

11. Viera C, Galvez C, Carrasco B, Santos C, Castellanos R. A study of peripheral neural conduction, motor and sensory, in diabetic patients treated with hyperbaric oxygenation Hyperbaric Oxygen Therapy and Neuropathy PMID: 15160386. PubMed - indexed for MEDLINE. 